IDEAS BEHIND SYMBOLS - LANGUAGES BEHIND SCRIPTS 
Studia uralo-altaica 52

\section{Redigunt}

Katalin Sipőcz

András Róna-Tas

István Zimonyi 


\section{Ideas behind symbols - languages behind scripts}

Proceedings of the 60th Meeting of the Permanent International Altaistic Conference (PIAC)

August 27 - September 1, 2017

Székesfehérvár, Hungary

Edited by Ákos Bertalan Apatóczky

Szeged, 2018 
(C) University of Szeged,

Department of Altaic Studies,

Department of Finno-Ugrian Philology

Printed in 2019

All rights reserved. No part of this book may be reproduced, stored in a retrieval system, or transmitted in any form or by other means, electronic, mechanical, photocopying, recording or otherwise, without the prior permission in writing of the author or the publisher.

Printed by: Innovariant Ltd., H-6750 Algyő, Ipartelep 4.

ISBN: 9789633066638 (printed)

ISBN: 978-963-306-664-5 (pdf)

ISSN: 01334239 


\section{Contents}

Preface

Tatiana Anikeeva

Turkic Manuscripts and Old-Printed Books of the Lazarev Institute of Oriental

Languages: Exploring the History of Oriental Studies in Russia

Chen Hao

Bark: A Study on the Spiritual World of the Early Türks

Oliver Corff

Nations and Rivers: Their Status and Name in the Qingshi Gao Reflections on the

Draft History of Qing as a Source

Balázs Danka

A language behind the script A case study on the Pagan Oyuz-nāmä

Mihály Dobrovits

The Ogur Turks in Chinese records

Hsiang-Tai Kao

The field research on the Manchu inscriptions in Beijing

Bayarma Khabtagaeva

Some notes on kinship terminology in Yeniseian.

Kyoko Maezono

Japanese and Mongolian Usages of the Chinese Writing System

Dieter Maue - Mehmet Ölmez - Étienne de la Vaissière - Alexander Vovin

The Khüis Tolgoi inscription

Rodica Pop

The "five eyes pattern" tavan nüden hee

Maria Magdolna Tatár

Bortz and Membrok, etymology of two Cuman names from the 13th century.....107

Hartmut Walravens

Józef Kowalewski’s Letters to Bernhard Jülg.

Tana $\mathrm{Wu}$

One Language behind Two Different Scripts*

Hülya Yıldız

New Reading Proposal on the Eastern Face, Nineteenth Line of the Bilgä Qayan Inscription 



\title{
Some notes on kinship terminology in Yeniseian
}

\author{
Bayarma Khabtagaeva \\ Szeged University \& Free University Berlin*
}

In Yeniseian languages certain criteria distinguish male and female classes. The present paper has a two-fold goal. First, it discusses the characteristics of derivation involved in the kinship terms in Kott, Arin and Pumpokol - the Yenisean languages where some kinship terms of Turkic origin are presented, - and, second, it analyzes these Turkic loanwords. The base of the paper is the monograph of Khabtagaeva (2019) on the Altaic elements of Yeniseian languages which was published recently.

\section{The Yeniseian languages}

The Yeniseian languages belong in the Palaeo-Asiatic (or Palaeo-Siberian) language group, which also includes the Yukaghiric, the Kamchukotic, the Amuric and the Ainuic languages ${ }^{1}$.

The earliest documented sources of Yeniseian languages are relatively recent. The first short lists of Yeniseian words and phrases were compiled at the end of the 17th and in the 18th centuries by European travelers such as Witsen (1692), Messerschmidt (1720-1727), and Strahlenberg (1730). The paucity of early written sources on Yeniseian is the reason why such an important role is played by the various loanwords in the reconstruction of the earlier stages of the history of the Yeniseian languages.

The most recent works on historical linguistics by Starostin (1982), Georg (2007: 16-20; 2018: 141), and Vajda (2014, personal communication) divide the Yeniseian languages into at least three sub-branches: Ket-Yugh, Pumpokol and Assan-Kott. Arin is either connected with Pumpokol or Ket-Yugh or represents a fourth subbranch. Today the Yeniseian language family is represented by only the three surviving dialects of Ket. The Yugh language lost its last fluent speaker in the 1970s, Kott disappeared before 1850, while Assan, Arin and Pumpokol vanished in the 1700 s.

* This paper is supported by the Alexander von Humboldt Foundation.

1 This term is conventionally used in linguistics to classify a group of languages spoken in different parts of northeastern Siberia and some parts of the Russian Far East. The languages of this group are not known to have any genetic linguistic relationship to each other. There have been attempts to include the Yeniseian languages in the Sino-Tibetan, Karasuk and Caucasian language families. In 2010 Vajda presented a hypothesis that the Yeniseian languages are genetically related to the Na-Dené languages of North America, but his results are still debated by several linguists; the question remains open. 
The main source of data for my monograph (Khabtagaeva 2019) was the Vergleichendes Wörterbuch der Jenissej-Sprachen by Werner (2002/1-3), which contains all of the lexical material published on the Yeniseian languages to date. Some data were collected from the monograph of the Yeniseian lexical material of the 18th century, published by Werner three years later (Werner 2005). Another very important source of my work was the Etymological dictionary of the Yeniseian languages by Vajda and Werner, which is still at a preparatory stage (Vajda \& Werner: in preparation).

According to the data, only Arin, Kott and Pumpokol borrowed from the Altaic languages words related to kinship. The material indicates that the terminology of kinship by blood is of Yeniseian origin; no loanwords are found there. There are some Turkic words among the Yeniseian terms concerning kinship by marriage, however, which is indicative of the practice of intermarriage between Yeniseian and Turkic people. There are no Mongolic loanwords and only one questionable term of Tungusic origin in Ket, which belongs in the category of uncertain etymology.

Despite the fact that the Yeniseian languages have clear rules with which to distinguish male and female noun classes as far as genitive or possessive suffixes, I faced certain problems during the research, since there are no grammatical descriptions of Arin or Pumpokol. Only brief word-lists are available from Werner's publications $(2002 ; 2005)$. There is more information on Kott: a detailed grammar and a small Kott dictionary (Castrén 1858; Werner 1990; 2005).

\section{Kinship terminology in Yeniseian}

The analysis of the Kott (Werner 2002; 1990: 55), Arin (Werner 2002; 2005: 154 168) and Pumpokol (Werner 2005: 179-187) nouns demonstrates their strict distinction between masculine, feminine, and neuter noun classes of words. Grammatical gender in Yeniseian is covert in the nominative and manifests itself in the genitive case. Some characteristics of the Yeniseian class system were briefly described by Werner and Živova (1981).

Table below demonstrates the distinction between classes in Kott:

\begin{tabular}{|c|c|c|c|}
\hline \multirow{2}{*}{ Class } & Nominative & Genitive & Meaning \\
\hline \multirow{3}{*}{ masculine } & haj & haja & 'uncle' \\
\cline { 2 - 4 } & boru & borua & 'wolf' \\
\cline { 2 - 4 } & fēnčera & fenčerā & $\begin{array}{c}\text { 'male wood } \\
\text { grouse' }\end{array}$ \\
\hline \multirow{2}{*}{ feminine } & āma & āmi & 'mother' \\
\cline { 2 - 4 } & fenčera & fenčerai & $\begin{array}{c}\text { 'female wood } \\
\text { grouse' }\end{array}$ \\
\hline \multirow{2}{*}{ neuter } & huš & 'huči & 'house' finger' \\
\cline { 2 - 4 } & $\mathrm{t}^{\mathrm{h}} \mathrm{ox}$ & $\mathrm{t}^{\mathrm{h}}$ ogi & \\
\hline
\end{tabular}


A good example of this distinction is also demonstrated by the kinship terminology.

1. There are some phonetic criteria that characterize the differences between the male and female classes:

a) The existence of the feminine suffix $-A$ in the words of the female class:

Arin akel 'son' ↔ akel'a 'daughter' (Werner 2005: 154);

Arin čen 'grandson' ↔ čene 'granddaughter' (Werner 2002/1: 165);

Kott pebě̌ 'brother' $\leftrightarrow$ pobeča 'sister' (Werner 2002/2: 55);

Kott $p^{h} u$ 'nephew' $\leftrightarrow p^{h} u a$ 'niece' (Werner 2005: 116);

Kott pateg 'wife’s brother' $\leftrightarrow$ patega 'sister-in-law' (Werner 2002/2: 52);

Kott $u c ̌ i t$ 'son-in-law' $\leftrightarrow$ učita 'sister-in-law' (Werner 2002/2: 320);

Kott hai 'uncle' ↔ hâja 'aunt' (Werner 2002/1: 293);

Kott hatkît 'husband' ↔ hatkīta 'wife' (Werner 2002/1: 308)

This suffix probably originates from parallel borrowing of the Russian femininegender inflection - $a$ (Vajda 2014: 510).

b) The existence of the final vowel $-i$, which may characterize the female class:

Arin mamagil 'brother's son' $\leftrightarrow$ mamagili 'sister's son' (Werner 2002/2: 17);

Kott $a n^{j} e$ 'son-in-law' $\leftrightarrow a^{j} e$ i 'daughter-in-law' (Vajda \& Werner: in preparation);

It is questionable, but this suffix is probably related to the Yeniseian genitive for the female class (Vajda 2013, personal communication).

c) The change $-p /-b>-m$ and the addition of the feminine suffix in the words of the female class:

Arin ajap 'father' $\leftrightarrow$ ajame 'mother' (Werner 2005: 154);

Arin bekib 'grandfather' ↔ bekime 'grandmother' (Werner 2005: 155);

Kott op 'father' $\leftrightarrow$ áma 'mother' (Werner 2002/2: 50, 95; Werner 2005: 107);

Kott $\boldsymbol{o b}$ 'father-in-law' $\leftrightarrow a \boldsymbol{m} \boldsymbol{a}$ 'mother-in-law; mother' (Werner 2002/2: 50, 95);

Kott xip 'grandfather' $\leftrightarrow$ xima 'grandmother' (Werner 2005: 120);

Pumpokol $a \boldsymbol{b}$ 'father' $\leftrightarrow a \boldsymbol{m}$ 'mother' (Werner 2005: 179) 
2. Compounding is a productive technique of word-formation in Yeniseian languages (for details, see Vajda 2014: 510-511).

a) Accordingly, there are some compound words in Yeniseian which are examples of kinship terminology:

Kott hatkît 'husband' (Werner 2002/1: 305) < *ka't 'old' + kît 'man' (Vajda \& Werner: in preparation);

Arin amagel 'brother' (Werner 2002/1: 32) < *amə 'mother' + *qal 'junior relative' (Vajda \& Werner: in preparation);

Arin bamagal'a 'sister' (Werner 2002/1: 101) < b- 'my' + *amə 'mother' + *qal 'junior relative' $+a$ \{FEMIN. SUFFIX\} (Vajda \& Werner: in preparation);

Kott pategapun 'husband's sister' (Werner 2002/2: 52) < pateg 'wife's brother' $+a$ FEMIN. SUFFIX $\}+$ pun 'daughter' (Vajda \& Werner: in preparation);

b) In the compound words, one element of the compound refers to the male or female class. Among the compound words reflecting kinship, one of the words indicates the female or male class:

Kott alitpuga 'granddaughter' (Werner 2002/1: 25) < alit 'female, woman' + puga 'grandson' (Vajda \& Werner: in preparation);

Kott pategapun 'husband's sister' (Werner 2002/2: 52) < pateg 'wife's brother' $+a$ FEMIN. SUFFIX $\}+$ pun 'daughter' (Vajda \& Werner: in preparation);

Kott pašupalitjali 'stepdaughter' (Werner 2002/2: 52) < pašup 'like, similar to' + alit 'female' + jali 'child', cf. pašupjali 'stepson' (Vajda \& Werner: in preparation);

Arin biq'ariat 'husband' (Werner 2002/1: 131) < bi 'my' $\{1$ SG.POSS.PREFIX $\}+q^{j} a r^{j} a t$ 'adult man' (Vajda \& Werner: in preparation);

The words above which have the $p \sim m$ alternation are likely to have originated from compounds too, since the second elements of these compounds are suffixes probably derived from $o b$ 'father' $\sim a m$ 'mother'.

3. There are some terms without any division of class, the words indicating either female or male persons:

Arin apati 'brother-in-law, sister-in-law' $<a$ - \{3SG.POSS.PREFIX $\}+$ *pateg 'wife's brother' (Werner 2002/1: 48); 
Kott pašûpše 'widow, widower' (Werner 2002/1: 52) < pašûp 'like, similar to' + še \{NOMINALIZER\} (Vajda \& Werner: in preparation);

Pumpokol akil 'brother, sister' (Werner 2005: 179);

Pumpokol bič 'brother, sister' (Werner 2005: 179);

Pumpokol xej-kit 'brother, sister' (Werner 2005: 187)

\section{Turkic loanwords in Yeniseian kinship terminology}

It seems that kinship terms of Turkic origin designate relatives through marriage. There are two groups of loanwords. One contains those loanwords which have a clear etymology, while the second group consists of words of unclear etymology.

1. The Turkic ${ }^{2}$ loanwords of clear etymology are as follows:

Arin kis 'sister-in-law' (Werner 2002/1: 479) $\leftarrow$ Turkic * qïs 'girl; unmarried woman; daughter': cf. Old Turkic qïz; YeniseiT: Khakas xïs; Koibal qïs (R); Kyzyl xïs; Shor qüs; AltaiT: Altai, Teleut qïs; Tuba, Qumanda, Quu kï; SayanT: Tuvan kis; Tofan qüs; ChulymT qï; Yakut, Dolgan qiis; Siberian Tatar qïs. ${ }^{3}$

Pumpokol $\boldsymbol{p}^{\boldsymbol{h}}$ ala $\sim$ falla $\sim$ fala 'son' (Werner 2002/2: 56) $\leftarrow$ Turkic *pala 'a human child, son': cf. Old Turkic bala 'child'; YeniseiT: Khakas, Shor, Sagai, Koibal, Kachin pala (R); Kyzyl pāla; AltaiT: Altai bala; Tuba pala; Qumanda pala bala; Quu, Teleut pala; SayanT - ; Yakut - ; ChulymT pala. $^{4}$

Kott bača 'brother-in-law (sister's husband)' (Werner 2002/1: 97) $\leftarrow$ Turkic * baja 'brother-in-law': YeniseiT: Khakas, Kyzyl paja; AltaiT: Altai bad'a; SayanT: Tuvan baža; Tofan baja; ChulymT pača; Yakut bad'a 'sister-inlaw'; Siberian Tatar pača paca $\leftarrow$ Mongolic: cf. Middle Mongol: HY baja; LM baja 'husbands of sisters; term used by husbands of sisters in referring to

2 Of the Turkic languages, only Siberian Turkic had direct linguistic contacts with Yeniseian. It seems that two layers may be distinguished: Yenisey Turkic and Altay Turkic. Rare similarities may be observed with Sayan Turkic, Chulym and Yakut languages.

3 The Common Turkic word is widespread in almost all Siberian Turkic languages, thus the source may be any one of them. The Turkic initial uvular consonant $q$ - is preserved in the Arin word, as in native Yeniseian words. From a semantic point of view, narrowing occurred 'girl, daughter' $\rightarrow$ 'sister-in-law'.

4 The Pumpokol forms relate to Turkic *bala 'child' (Stachowski 1997: 232). The source of borrowing was the Turkic form with the unvoiced initial consonant $p$-, which is peculiar of some Siberian Turkic languages. Another reason for the source of the word to be the Turkic form pala is that Pumpokol has the initial consonants $p^{h}$ - and $f$-, and these go back to the ProtoYenisieian initial * $p$ - (Starostin 1982: 149). 
each other'; Modern Mongol: Buryat baza 'brother-in-law'; Khalkha badz 'brothers-in-law, husbands of sisters'; Kalmuck baza 'brother-in-law'; Dagur badz; Khamnigan badza. ${ }^{5}$

Arin bi-b'ača 'brother-in-law' (Werner 2002/1: 97), with the Yeniseian possessive prefix $b i$ - 'my'.

The point remains open regarding another Arin word, bib' $a$ 'sister-in-law'. This is probably connected with the examined Arin word bi-b'ača 'brother-in-law', where the final syllable $-\check{c} a$ was dropped. Unfortunately, there is no similar example to strengthen this hypothesis.

2. There are some compound loanwords of Turkic origin:

The Arin form oj 'step-' was clearly borrowed from Turkic, with secondary long vowel $\ddot{\partial} y$, which indicates a later period of borrowing. This form is characteristic of almost all Siberian Turkic varieties. Some researchers (for details, see ESTJa 1974: 495-496) connect the Turkic word with the Mongolic negation word $\ddot{u} g e i$ (for its function, see Poppe GWM §632). I consider it as a half-affix of Turkic origin (Khabtagaeva 2019: 345-346).

It is important to remark that the half-affixes of Turkic origin follow the Turkic word order, the half-affix in the first syllable, while in Yeniseian the half-affix is in the second syllable: compare some Ket words such as ammas 'stepmother', hunnas 'stepdaughter' and oppas 'stepfather' with Yeniseian half-affix *pas, which denotes a non-consanguineous relationship.

Arin ojče 'stepmother' (Werner 2002/2: 32) $\leftarrow$ Yenisei Turkic öy 'step-' + ije 'mother': Khakas öy ije; Sagai, Koibal, Kachin $\overline{\ddot{y} y ~ i \jmath a ̈: ~}$

< Turkic: Old Turkic ögey 'related through one parent only' + eče 'one's mother's younger sister'; cf. Altai öy ene 'stepmother';

+ ije < eče 'mother': cf. Old Turkic eče 'one's mother's younger sister; one's own elder sister'; YeniseiT: Khakas ije 'mother'; Sagai iðä; Koibal, Kachin ijä; Shor $\ddot{u} \dddot{\jmath} \ddot{a}$ 'grandmother from father's side'; AltaiT: Altai ed'e 'aunt; elder sister', cf. ači 'father's younger brother'; Tuba ed'e 'aunt; elder sister; mother'; Qumanda ed'e 'aunt, elder sister'; Quu edže eže 'elder sister, sister'; Teleut eye 'aunt, elder sister'; SayanT: Tuvan ača 'father'; Tofan aja

5 The etymology of the Turkic word is unknown: it is present in almost all Turkic languages, but it is absent in Old Turkic. We find the word also in Mongolic languages, but it is not clear whether it is borrowed from Turkic, or if it is a native Mongolic word which was borrowed by the Turkic languages. Doerfer poses a question concerning the Mongolic data, and classifies the Turkic word as a "child word" (TMEN 2: 232-233). From Mongolic, the word was borrowed into the Barguzin Ewenki dialect of Tungusic baja 'brother-in-law' (SSTMJa 1: 63). 
'father', cf. iche 'mother'; ChulymT ècä 'mother'; Yakut iye 'mother', cf. ehe 'grandfather; bear'; Siberian Tatar -.6

This Turkic compound word was borrowed by Samoyedic Kamas, cf. ugeija 'stepmother' (Joki LS 136-137; 250). As compared with the Yeniseian form, the Kamas form preserved the Turkic pattern -öge-, which points to an earlier time of borrowing.

The following two compound words in Yeniseian are hybrid words, where one element is Turkic, the other Yeniseian:

Arin ojakelbala 'stepson' (Werner 2002/2: 32) < oj + Yeniseian akel 'son' + bala

$\leftarrow$ Turkic $\ddot{o y}$ 'step-' + bala 'child': cf. Yenisei Turkic: Khakas öy pala; Shor, Sagai, Koibal, Kachin $\overline{\ddot{u} y}$ pala $\sim \bar{o} y$ pala; Altai Turkic: Altai, Teleut $\overline{o y}$ pala;

Arin ojakel'a 'stepdaughter' (Werner 2002/2: 33) < oj + Yeniseian akel'a 'daughter' < akel $+a$ \{FEMIN. SUFFIX\}

$\leftarrow$ Turkic $\bar{o} y$ 'step-': cf. Old Turkic ögey 'related through one parent only';

3. The last group consists of Yeniseian words which do not have a reliable or clear etymology:

Arin čerč'učagan 'wife's brother' (Werner 2002/1: 165) $\leftarrow$ ? Turkic *jeste 'brother-in-law' + *jagan 'older, estimable, venerable': cf. AltaiT: Altai $d$ 'ān d'este 'aunt's husband from father's side'; cf. Quu d'este 'brother-in-law'; Tuba d'este; YeniseiT: Khakas čiste 'elder sister's husband';

The Turkic etymology of the Arin word is problematic in two respects. One of them is the incorrect order of the words, following the pattern noun + adjective, while the correct sequence would be adjective + noun. Another counterargument against a Turkic etymology is the presumable assimilation of $*^{2}$ eréč $u<*^{*}$ ést' $u<$ *jestü $<$ *jeste.

The last two Kott words are likewise problematic:

Kott monmonigaiob 'stepfather' (Werner 2002/2: 21) < mon 'not, no' + *monigai + ob 'father' (Vajda \& Werner: in preparation);

Kott monamanig/a]ama 'stepmother' (Werner 2002/2: 21) < mon 'not, no' $+a$ FFEMIN. SUFFIX $\}+*$ manig $[a]+a m a$ 'mother' (Vajda \& Werner: in preparation);

The unclear parts of the words *monigai and *manig[a] can be related to Yenisei Turkic (cf. Khakas mayat 'very good', cf. magat 'kind, honest, fair, justified'; Sagai,

6 The Turkic word eče 'mother' belongs to 'child language', which is difficult to etymologize. The Turkic word eče 'mother' was probably borrowed by Mongolic. Cf. Turkic $\rightarrow$ Mongolic 'mama (familiar term)': Middle Mongol: - ; LM eǰi; Modern Mongol: Buryat ežï; Khalkha ēj; Oirat dial. $\bar{e} d \check{z} \check{l} \sim \bar{e} \bar{z} \sim \bar{e} d \check{z}$; Dagur - ; Khamnigan idžé. 
Shor magat 'good, efficient, honest') according to the reconstruction *mayat <

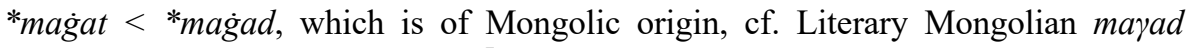
'sure, certain, true, probable, real'?

\section{Conclusion}

The Altaic loanwords expressing kinship in Yeniseian indicate that the Yeniseian and Turkic people intermarried. The blood kin terminology is of Yeniseian origin.

From a phonetic and morphological respect, the loanwords belong to a later period of borrowing; they do not behave according to the phonetic rules of Yeniseian, and they do not take any of the suffixes that play an important role in the distinction between the Yeniseian male and female classes.

\section{References}

Altay = Baskakov \& Toščakova 1947

Baskakov, N. A. (ed.) (1953) Hakassko-russkij slovar'. Moskva.

Baskakov, N. A. (1966) Dialekt černevyh tatar (tuba-kiži), Severnye dialekty altajskogo (ojrotskogo jazyka). Grammatičeskij očerk i slovar'. Moskva.

Baskakov, N. A. (1972) Dialekty kumandincev (kumandy-kiži). Severnye dialekty altajskogo (ojrotskogo) jazyka. Grammatičeskij očerk, teksty, perevody i slovar'. Moskva.

Baskakov, N. A. (1975) Dialekt lebedinskih tatar-čalkancev (kuu-kiži). Grammatičeskij očerk, teksty, perevody i slovar'. Moskva.

Baskakov, N. A. \& Toščakova, T. M. (1947) Ojrotsko-russkij slovar’. Moskva.

Bawden, Ch. (1997) Mongolian-English Dictionary. London \& New-York.

Birjukovič, R. M. (1984) Leksika čulymsko-tjurskogo jazyka. Posobie k speckursu. Saratov: Izdatel'stvo Saratovskogo Universiteta.

Buryat $=$ Čeremisov 1973

Castrén, M. Alexander (1858) Versuch einer jenissei-ostjakischen und kottischen Sprachlehre. St. Petersburg.

Čeremisov, K. M. (1973) Burjatsko-russkij slovar'. Moskva.

Chulym = Birjukovič 1984

Cincius, V. I. (ed.) (1975) Sravnitel'nyj slovar' tunguso-man'čžurskix jazykov 1-2.

Clauson, G. (1972) An etymological dictionary of Pre-thirteenth-Century Turkish. Oxford.

7 Cf. Middle Mongol: Precl.Mo. mayad; MNT; HY maqa(t); Muq. maqat; LM mayad 'surely, certainly, truly; probable, probably, really, indeed, undoubtedly; most likely; certainly, determination, reality'; Modern Mongol: Khalkha; Buryat; Khamnigan magad; Kalmuck mayad. 
Coloo, J. (1988) BNMAU dax' mongol xelnii nutgiin ayalguunii tol' bičig. Oird ayalguu. Ulaanbaatar: Ulsyn xevleliin gazar.

Dagur = Engkebatu 1984

Damdinov, D. G. \& Sundueva, Je. V. (2015) Xamnigansko-russkij slovar'. Irkutsk.

Doerfer, G. (1963-1975) Türkische und mongolische Elemente im Neupersischen. 1-4. Wiesbaden.

Dolgan = Stachowski 1993

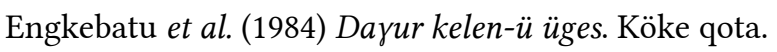

ESTJa 1974 = Sevortjan 1974

Georg, S. (2007) A descriptive grammar of Ket (Yenisei-Ostyak). 1: Introduction, phonology, morphology. Folkestone/Kent.

Georg, S. (2018) Other isolated languages of Asia. In: Campbell, L. (ed.): Language isolates. London \& New York: Routledge. 139-161.

Haenisch, E. (1957) Sinomongolische Glossare 1. Das Hua-I ih-yü. Abhandlungen der Deutschen Akademie der Wissenschaften zu Berlin 1956: 5. Berlin.

HY = Haenisch 1957

Janhunen, J. (1990) Material on Manchurian Khamnigan Mongol. Helsinki.

Joki LS = Joki A. J. (1952) Die Lehnwörter des Sajansamojedischen. Helsinki.

Joki, A. (1953) Wörterverzeichnis der Kyzyl-Sprache. Helsinki.

Kalmuck = Ramstedt 1935

Khabtagaeva, B. (2019) Language Contact in Siberia: Turkic, Mongolic, and Tungusic loanwords in Yeniseian. Leiden \& Boston: Brill.

Khakas = Baskakov 1953

Khalkha = Bawden 1997

Khamnigan = Janhunen 1990; Damdinov \& Sunduva 2015

Kurpeško-Tannagaševa, N. N. \& Apon'kin, F. Ja. (1993) Šorsko-russkij i russkošorskij slovar'. Kemerovo: Kemerovskoe knižnoe izdatel'stvo.

Kyzyl = Joki 1953

Lessing, F. D. (1996) Mongolian-English dictionary. Bloomington.

LM = Lessing 1996

Oirat dial. $=$ Coloo 1988

Old Turkic $=$ Clauson 1972

Pekarskij, E. K. (1959²) Slovar' jakutskogo jazyka. 1-3. Leningrad.

Poppe GWM = Poppe, N. (1964) Grammar of Written Mongolian. Wiesbaden: Harrassowitz.

Qumanda = Baskakov 1972

Quu = Baskakov 1975 
R = Radloff, W. (1893-1911) Versuch eines Wörterbuches der Türk-Dialecte. 1-4. St. Petersburg.

Ramstedt, G. J. (1935) Kalmückisches Wörterbuch. Helsinki.

Rassadin, V. I. (1995) Tofalarsko-russkij slovar'. Russko-tofalarskij slovar'. Irkutsk.

Sevortjan, Ė. V. (1974) Ėtimologičeskij slovar' tjurkskix jazykov. Obščetjurkskie i mežtjurkskie osnovy na glasnye. Tom 1. Moskva.

Shor = Kurpeško-Tannagaševa \& Apon'kin (1993)

Siberian Tatar $=$ Tumaševa 1992

SSTMJa = Cincius 1975

Stachowski, M. (1993) Dolganischer Wortschatz. Kraków.

Stachowski, M. (1997) Altaistische Anmerkungen zum "Vergleichenden Wörterbuch der Jenissej-Sprachen”. Studia Etymologica Cracoviensia 2. 227-239.

Starostin, S. A. (1982) Praenisejskaja rekonstrukcija i vnešnie svjazi enisejskix jazykov. In: Ketskij sbornik. Antropologija, ètnografija, mifologija, lingvistika. Leningrad. 144-237.

Teleut = Rjumina-Syrkaševa \& Kučigaševa 1995

Tenišev, E. R. (ed.) (1968) Tuvinsko-russkij slovar'. Moskva.

TMEN = Doerfer 1963-1975

Tofan = Rassadin 1995

Tuba = Baskakov 1966

Tumaševa, D. G. (1992) Slovar' dialektov sibirskix tatar. Kazan'.

Tuvan = Tenišev 1968

Vajda, E. \& Werner, H. (in preparation): Yeniseian Etymological Dictionary. (appr. 1.000 p.)

Vajda, E. J. (2010) A Siberian Link with Na-Dene Languages. In: Kari, J. \& Potter, B. (eds.) The Dene-Yeniseian Connection. Anthropological Papers of the University of Alaska 5. Fairbanks: University of Alaska Fairbanks, Department of Anthropology. 33-99.

Vajda, E. J. (2014) Yeniseian. In: Lieber, R. \& Štekauer, P. (eds.) The Oxford Handbook of derivational morphology. Oxford: Oxford University Press. 509-519.

Werner, H. [= Verner, G.K.] \& Živova, G.T. (1981) K xarakteristike klassnoj sistemy v jenisejskix jazykax. Voprosy jazykoznanija 5. 31-38.

Werner, H. [= Verner, G. K.] (1990) Kottskij jazyk. Rostov-na-Donu.

Werner, H. (2002) Vergleichendes Wörterbuch der Jenissej-Sprachen. I-III. Wiesbaden: Harrassowitz.

Werner, H. (2005) Die Jenissej-Sprachen des 18. Jahrhunderts. Wiesbaden: Harrassowitz.

Yakut = Pekarskij 1959 